\title{
Men serving long-term sentences in Zonderwater Correctional Centre, South Africa: Religious identity and behavioural change
}

\begin{tabular}{|c|c|}
\hline \multicolumn{2}{|c|}{ 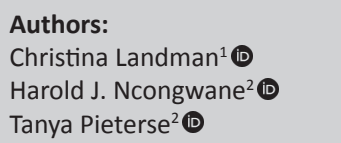 } \\
\hline \multicolumn{2}{|c|}{$\begin{array}{l}\text { Affiliations: } \\
{ }^{1} \text { Research Institute for } \\
\text { Theology and Religion, } \\
\text { University of South Africa, } \\
\text { Pretoria, South Africa }\end{array}$} \\
\hline \multicolumn{2}{|c|}{$\begin{array}{l}{ }^{2} \text { Department of Psychology, } \\
\text { University of South Africa, } \\
\text { Pretoria, South Africa }\end{array}$} \\
\hline \multicolumn{2}{|c|}{$\begin{array}{l}\text { Corresponding author: } \\
\text { Tanya Pieterse, } \\
\text { tanyap@global.co.za }\end{array}$} \\
\hline \multicolumn{2}{|c|}{$\begin{array}{l}\text { Dates: } \\
\text { Received: } 26 \text { Sept. } 2018 \\
\text { Accepted: } 07 \text { Nov. } 2018 \\
\text { Published: } 27 \text { Mar. } 2019\end{array}$} \\
\hline \multicolumn{2}{|c|}{$\begin{array}{l}\text { How to cite this article: } \\
\text { Landman, C., Ncongwane, } \\
\text { H.J. \& Pieterse, T., 2019, } \\
\text { 'Men serving long-term } \\
\text { sentences in Zonderwater } \\
\text { Correctional Centre, South } \\
\text { Africa: Religious identity } \\
\text { and behavioural change', } \\
\text { HTS Teologiese Studies/ } \\
\text { Theological Studies } \\
75(3), \text { a5274. https://doi. } \\
\text { org/10.4102/hts.v75i3.5274 }\end{array}$} \\
\hline \multicolumn{2}{|c|}{$\begin{array}{l}\text { Copyright: } \\
\text { (C) 2019. The Authors. } \\
\text { Licensee: AOSIS. This v } \\
\text { is licensed under the } \\
\text { Creative Commons } \\
\text { Attribution License. }\end{array}$} \\
\hline \multicolumn{2}{|l|}{ Read online: } \\
\hline 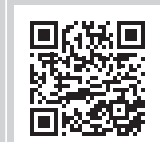 & $\begin{array}{l}\text { Scan this QR } \\
\text { code with your } \\
\text { smart phone or } \\
\text { mobile device } \\
\text { to read online. }\end{array}$ \\
\hline
\end{tabular}

\begin{abstract}
This article retrieves the voices of a group of incarcerated men speaking on their religious identity and the behavioural changes ensuing from their religious choices. Research data were collected over a 10-month period from participants that consisted of a group of 30 male offenders serving life or long-term sentences at the Correctional Centre A, Zonderwater Management Area in Cullinan near Pretoria, South Africa. Qualitative research by means of an interview schedule invited offenders to share their thoughts on how their religious beliefs and experiences served as a support system during incarceration. Insight was gained into how religious identities were established to maintain a sense of belonging and hope during this period. The study embraces the Social Identity Theory that departs from the premise that individuals have multiple identities associated with the environment they live and operate in. Interpretative phenomenological analysis was used to understand the shaping of religious identity within the four themes that were identified: conserving identities; accommodating identities; contraidentities; and change of behaviour, attitudes and values. Research on religious identities operationalising into behavioural change provides knowledge to disciplines such as psychology, sociology and theology, and assists the correctional services in understanding the complex and dynamic nature of offenders when they voice themselves outside of their crimes.
\end{abstract}

\section{Introduction}

The study contributes to the understanding of how religion serves as a support system for male offenders serving life or long-term sentences at Correctional Centre A, Zonderwater Management Area. To achieve this understanding, the study aims, firstly, to explore the religious lived experiences of a group of male offenders in their search for religious identity during incarceration. Secondly, the aim is to describe how the male offenders' experiences and religious identity shape their behaviour. Terms such as religion, religiosity, faith and spirituality are used interchangeably in this study to refer to the belief system of an interviewee.

Through a semi-structured questionnaire, 30 participants were provided an opportunity to give voice to their life stories as offenders serving life or long-term sentences and share how their religious and spiritual experiences act as a support system during their incarceration. Thus, valuable insight was gained in how, compared to before their incarceration, religious identities were either newly established, adjusted or conserved in maintaining a sense of belonging and hope during incarceration. Often, though not always, preferred and new religious identities operationalised in behavioural change provide knowledge to disciplines such as psychology, sociology and theology, and assist correctional services in understanding the social identity of the incarcerated.

In what follows, Social Identity Theory (SIT) as the philosophy informing this study will be explained. Thereafter, the process of data collection will be described, and interpretative phenomenological analysis (IPA) as the method of interpreting the data will be implemented. Finally, the relationship between religious identity and behavioural change will be explored and discussed as it has transpired from amongst this group of men serving sentences of longer than 15 years.

\section{Social identity theory and religious identity}

SIT as developed by Tajfel and Turner (1986:276), founded upon the premise that individuals have multiple identities in the groups they affiliate to, which regulate behaviour within that specific social context. Identity, according to Ashforth and Mael (1989:21), comprises personal identity,

Note: The collection entitled 'Eben Scheffler Festschrift', sub-edited by Jurie H. le Roux (University of Pretoria) and Christo Lombaard (University of South Africa). 
which includes characteristics such as physical attributes, abilities, psychological traits and interests, as well as a social identity, which encompasses various characteristics of the self, as well as the significant group characteristics in which the individual functions. Individuals classify themselves in categories that can range from organisational membership, gender, age and race to (as of interest to this study) religious affiliation. This form of self-categorisation, as referred to by Turner et al. (1987:42), is a process whereby individuals categorise their own identities at different levels, such as individual level, relational level, small group level and large group or social level. These multiple identities, operating within a specific space, enable them to orientate or define themselves within a social environment (Tajfel \& Turner 1986:283).

SIT has been widely used to understand group processes in relation to individual identities, and how participation in an affiliation to a social group aids in forming, defining and redefining their identity (Greenfield \& Marks 2007:247). Social identification regards the perception or sense of belonging to some human collective or group (Ashforth \& Mael 1989:21), for example, as in the case of the participants, a male offender may define himself as being a South African male, father, husband, brother, co-offender, incarcerated, serving a life or long-term sentence in a maximum correctional facility, church member, Christian, Muslim, Jew, Atheist or Agnostic. Through his affiliation to a group, he recognises, amongst others, the identity, goals, characteristics, values and attributes of the group as his own.

Guided by SIT, the researchers explored the forming of the social and religious identities of the offenders, and the role of social groups, such as religious affiliation, in the formation of new identities. Regarding one's selfcategorisation we may find that, for example, some individuals may perceive their own religious identity as a personal characteristic, whereas others perceive it as belonging to a specific group (Brambilla et al. 2016:189). In studies on religious identity, identity has been studied both as a social self and an individual self. In this regard, the social self refers to the social aspects of religion, for example, group belonging, participation in rituals, singing and so on, whereas the individual self refers to the individual aspects of religion, as solitary prayer, personal beliefs and individual relationship with God or the transcendent (Brambilla et al. 2016:189).

According to Ysseldyk, Matheson and Anisman (2010:60), the affiliations of individuals to a specific group or interest group shape and enhance their identities. In other words, as individuals relate to values, structures and roles within a specific social group, their identities are also affected. Although there are various ways to conceptualise social groups, various authors depict a social group as a collection of individuals who share the same interest and who may classify themselves as belonging to one social category (Turner et al. 1987, 1994). This notion suggests a dual process involved in identity formation from a social identity perspective, namely, the group processes, dynamics and characteristics, which shape the identities of an individual and the cognitive and motivational state that lead to structural group characteristics (Greenfield \& Marks 2007:247), thus indicating the importance of both individual and group processes as factors that mediate identity.

Individuals who have identified with the same religious group view their group affiliation as central to their selfconcept, enhancing their self-esteem (Haslam et al. 2009:3). According to Greenfield and Marks (2007:247), the belief system that is inherent to religious membership assists us in understanding why some individuals affiliate themselves with a specific religious group. However, Deaux (cited in Ysseldyk et al. 2010:61) argue that a belief may also stem from social, cultural and psychological foundations where belief systems arise from attitudes towards a specific issue. Nonetheless, belonging and participating in religious activities guide individuals in giving meaning to events in their lives. Also, various authors have highlighted that highly religious individuals tend to avoid criminal activities, as they accept social norms, which promote good conduct (Ysseldyk et al. 2007:62).

Given the complex and diverse environment of corrections and the various role players involved, the process of identity formation and sense making may often cause ambiguity and discomfort within this institutional context where coping is compromised (Riley 2000:361). Sensemaking is a continuous process of shaping reality, where action and context determine the elements of making sense and understanding the events and forced environment in which one has to cope (Bolander \& Sandberg 2013:287).

As background to the role of spirituality and religion during incarceration, we refer to research conducted by Richard Shaw (1995) at the Albany male correctional centre in the US, where he explored three faces of religious behaviour and religiosity. He refers to them as (1) Riding the religious pony, (2) Religion as comfort and (3) God trips. In the first face, he observes that it is not an uncommon phenomenon in correctional centres to have so-called Bible punchers, who use their religion in attempts to influence officials of the parole board. A second observation made is that very few offenders have a stable religious background when entering the centre. During incarceration, however, many offenders seek comfort in religion. Thirdly, he mentions that offenders who have committed crimes that are regarded as particularly despicable by society often become born-again while incarcerated and often show a fascination for fundamentalist religion (Landman 2005:790).

In this study, as will be explained later, we found no reason to develop, as a separate theme, the exploitation of religion for parole and other benefits amongst the interviewees. However, we found amongst them two extreme tendencies, that is, either to return to (previous) forms of fundamentalist religiosity or to radically change religious affiliation. 


\section{Behavioural change from a psychological perspective}

The question, why do we behave the way we do? has remained a topic of intensive research and many theories. One of the earlier theories is that of Albert Bandura (1971:1), who found that behaviour was influenced by forces from within us, in the form of needs, drives and impulses, often on a subconscious level. As the thinking developed around this approach, it was suggested that human behaviour was not merely an internalised process, but was learnt, shaped by observation and responsive to external influences. Furthermore, behaviour was regarded as having a causal relationship to external stimuli, driven by punishment and rewards. As much as behaviour is a response to environmental influences, it was later argued that as humans we are not merely reacting helplessly to outside stimuli (Bandura 1999:6). The social cognitive learning theory by Julian Rotter, Albert Bandura and Walter Mischel forthwith acknowledges that environmental influences are important determinants of behaviour; however, allowance must be made for people's ability to influence their own behaviour and development (Bandura 1999; Meyer, Moore \& Viljoen 2008). This theory presumes that people live within a system, with different daily situations impacting on them, requiring them to react.

However, people are not merely reactory beings, such as Pavlov's dog, behaving by mere classical conditioning or instinct (Windholz 1986:324), but are continuously in interaction with the situation and capable of self-regulation. In this regard, people are guided by previous experiences as well as by their cognitive capacity that not only direct their reaction to a situation in the present moment but also have an impact on their future behaviour (Bandura 1971:3). This approach enhances the thinking around people as interactional beings whose reactions are determined by three factors, namely the person, situation and behaviour. The interaction between the person and situation results in a specific response or behaviour, and the person is described as a locus where certain processes take place, such as observation, planning, control and judgement, which direct their behaviour (Bandura 1999:7).

In discussing human behaviour, one has to look at the determinants of behaviour that guide the interactions between these two factors, namely, attitudes and values. Attitudes are beliefs around specific objects or situations, often reflecting multiple, changing opinions (Nordlund 2009:4). This involves a process whereby people evaluate concepts in their lives. Feelings or an attitude towards something only develop once a person responds to a certain object, subject or matter (Nordlund 2009:4). This process involves three components, namely a cognitive, affective and behavioural response. In terms of cognition, it refers to thoughts, ideas and beliefs towards an object and an effective response refers to emotions, mood and feelings towards an object or matter. Behavioural response in turn involves a person's actions, or intentions to act, towards an object (Nordlund 2009:4). This study reports how the behaviour and attitude of the interviewees have presented and changed based on the religious identities they have assumed during incarceration.

\section{Data collection and ethical compliance}

Research data were collected over a 10-month period, from June 2017 to March 2018, from 30 male offenders, incarcerated at the Correctional Centre A, Zonderwater Management Area, near Cullinan, a small town $50 \mathrm{~km}$ to the east of Pretoria. Participants were selected by means of purposive sampling with set criteria, which included: (1) adult male offenders incarcerated at the mentioned centre; (2) participants to have experienced a lifestyle change leading to crime cessation, or at least shown evidence of having made significant progress towards a lifestyle change; and (3) the offender to have indicated that his lifestyle change can be connected to his religious beliefs and experiences.

Permission and ethical clearance were granted by the ethics committee of the Department of Psychology at the University of South Africa (UNISA), as well as by the Department of Correctional Service's Ethics Committee.

This study complies with the principles of ethical research, namely autonomy, non-maleficence, beneficence and justice (Terre Blanche, Durrheim \& Painter 2012:67-68). To treat all participants with dignity, respect and confidentiality, a Letter of Consent was provided to and signed by each participant. At the beginning of each interview, the participant was informed about the nature, purpose and method of the study. Permission was granted to audio record the interview, and the participant was informed about his right to withdraw at any time. Participants were informed that the study was for research purposes only, that it had no bearing on their sentence and that the information gathered would not be disclosed to any third party for parole purposes.

To address the principle of beneficence, it is envisaged that this study will benefit not only the offender but also the corrections fraternity and that the benefits will by far outweigh the risks. Serving the principle of justice, the researchers declare that no participant was exploited at any time and was acknowledged as part of a vulnerable community. The psychologist and the social worker at Correctional Centre A, Zonderwater Management Area served as gatekeepers, and assisted in selecting appropriate participants. Owing to their regular sessions with offenders, the gatekeepers assisted in identifying possible volunteers to participate that met the set criteria. Through their engagements over time, they had the best knowledge of any lifestyle changes that have occurred that could be of significance to this study.

Data were collected by conducting 30 semi-structured interviews to elicit the lived experiences of offenders and determine how their religious and spiritual experiences serve 
as support system during incarceration. An interview schedule was developed to guide the discussions and to gather optimal data on the experiences of the participants. However, the researchers had an open mind when approaching the interview by listening to salient experiences. The contents of the questions prompted the interviewees to talk about the meaning their religious affiliation afforded them during incarceration and how these religious affiliations changed or remained unchanged since the inception of incarceration. The structure of the interview schedule evolves from broader to narrower questions (a funnel sequence) to ensure that a broad range of categories are canvassed, while at the same time allowing for structure.

\section{Data analysis}

This study follows an IPA approach to explore the lived experiences of offenders and how their religious experiences serve as a support system during incarceration. Data analysis by means of IPA is characterised by three main features. Firstly, it is idiographic in nature, which entails a case-by-case detailed analysis of themes until a specific conclusion is reached of each case, phenomena, individual or group's perceptions and understanding of their lived experiences (Smith 2004:41). IPA is selected as the preferred method for this study, in that it enables researchers to focus on the particular rather than the universal or the generalised (Pietkiewicz \& Smith 2014:8). The second feature of IPA is that it applies an inductive technique (Smith 2004:43), whereby data analysis is flexible in allowing for unanticipated topics or themes to emerge. Researchers collect rich, expansive data, rather than merely testing a specific hypothesis. The rationale of using this approach was to determine the essence and meaning that participants articulate to their religious and spiritual identity and how this impact on their behaviour. A third feature regards an interrogative approach, whereby, through constructive dialogue, sharing constructs and concepts between various fields of study such as psychology, theology or sociology, contribute to the body of knowledge of these disciplines (Smith 2004:43).

On analysing the data by means of IPA, the researchers are provided an opportunity to understand the stories told by the participants, of their lived experiences as offenders, without alteration and counter-judgement. This approach shifts the focus of research towards the understanding of the participants' way of making sense of their experiences (Smith 2004:48). The concept of phenomenology was founded by Husserl in 1931 with the intention of understanding how participants find meaning in their experiencing of a phenomenon, as in this case religion and spirituality (Pietkiewicz \& Smith 2014:8). This study therefore explores how individuals experience, perceive and talk about their religious experiences, rather than describing phenomena according to a set construct, categorical system or scientific criteria (Pietkiewicz \& Smith 2014:8).

Through the process of analysing and exploring the phenomenon of religion as a support system, valuable insight was gained as to the search for, and forming of, religious identity, as well as on how the male offenders' experiences and religious identity shape their behaviour. In this dynamic process of making sense of the participants' experiences, the meaning they attach to it and how this shapes their religious identity, the researcher plays an active role (Smith \& Osborne 2008:53) and is strongly connected to the interpretative tradition. The value of this process lies in the fact that the participants try to make sense of their lives as spiritual beings who are incarcerated, while the researcher, embedded in this process, makes sense of the participant's sensemaking within his or her own framework and world (Smith 2004:48).

\section{Themes within religious identity formation during incarceration}

Data were collected from a sample of participants who are affiliated to a variety of religious orientations within Christianity and Islam. Two more participants who call themselves atheists were sampled as negative sampling. The total number of interviews is 30 .

The participants' religious affiliation is spread across various sub-categories:

- Eight belong to Christian mainline churches, including a Baptist, two from the DRC, a Methodist, two Presbyterians, one from the Afrikaanse Protestantse Kerk and one from the Ou Apostoliese Kerk. One belongs simultaneously to the Anglican Church and practised Buddhism.

- One participant calls himself a Messianic Jew, and five more Messianic Israelites. One is from the 'Israel Church'.

- Four belong to a church established locally in the correctional facility, the Commission of Christ Redeemer. Three more are apostles and leaders in churches, which they themselves have established in the correctional facility.

- There are also three members of the ZCC (Zion Christian Church).

- There are two Muslims.

- Two call themselves at times Atheist.

- One participant wants himself to be referred to as 'No label' but sometimes indicates that he leans towards Hindu Brahmanism.

In terms of age, one offender is in his 20 s and one in his 60 s. The majority falls in between. Eleven are in their 30 s and 13 in their 40s. Four are in their 50s.

The sample consists of 13 white, 15 black and two mixed race male offenders.

Of the participants, 29 participants are South African, while one participant is from Tanzania.

Thirteen of the participants use Afrikaans as their mother tongue, and two English. Three speak mainly Southern Sotho, one Pedi, one Tshwana, one Tsonga, two Xhosa, two Zulu, one Ndebele, one Swazi, two Venda and one (participant from Tanzania) Swahili. 
In the following sections of this article, the authors will retrieve the voices of the participants to describe how religiosity acts as a support system during the male offenders' time of being incarcerated. Guided by SIT, the authors will discuss how their religious identities were formed and were embodied as a support system.

By applying IPA, researchers were able to identify themes that support the objectives and aims of this study, and to distinguish the following three religious identities that were formed during incarceration, namely a conserving religious identity, an accommodating religious identity and a religious contra-identity. Listening to how they experience religiosity and have formed a religious identity enabled the researchers to furthermore explore how these newly formed or renewed religious identities altered or changed their behaviour. These four themes - conserving identity, accommodating identity, contra-identity and behavioural change - will now be discussed and supported by the voices of the participants (indicated by a ' $\mathrm{P}$ ') themselves.

\section{Conserving religious identities}

The notion of conserving identity relates to the experience of participants whose religious identity remained the same after being incarcerated. Furthermore, their religious affiliation remained untouched although it is sometimes expanded to include attending visits from a variety of religious workers who are permitted to work in the correctional facility. The following quotations illustrate this notion:

\begin{abstract}
'You know what, in this, I'm gonna be honest with you, it has not changed me. Okay? It hasn't changed me. Look, outside I wasn't reading my Bible but now I am reading my Bible. Okay outside I wasn't praying, now I pray. So, if one says how religion has changed me, maybe when I was outside I wasn't relying on God. I've always said I don't want to change myself, hey, okay I don't. I really don't want to change myself. I know who I am, I know I'm a good person, I know that.' (P 1)
\end{abstract}

The narration by this participant depicts the conservation of identity. He narrates that although his behaviours outside were different from current behaviours such as praying and reading the Bible more often and relying on God, his identity remained the same. It seems that being incarcerated provided him with more structure and time for spiritual activities, and an opportunity to rely on God:

'I was born in the family of the ZCC members. I was raised in the church. In that church, you are not baptised until you are fully matured to take responsibility for the steps you are taking. So, I was in the church until I was baptised and being a full Christian at sixteen years old. And I followed this church because all I see now about the church it was a good thing to be in the church.' (P 2)

The above narrative illustrates two notions, namely that identity is both an individualistic and social group process. The narration from this participant depicts individualistic processes that facilitate identity development, stemming from his religious affiliation. Therefore, the notion of identity is not only a by-product of group social affiliation but also individualistic in that individuals can shape their religious identity. Furthermore, although their environment has significantly changed because of incarceration, the essence of being and identity has been conserved and thus participants found the experience of conserving identities meaningful.

Another significant feature of a 'conserving religious identity' is displayed by the following participant who has remained a traditional Christian since incarceration, but 'deepened' his religious experience by recovering the Old Testament laws and feasts, celebrating the latter to give a meaningful structure to his otherwise empty days:

\footnotetext{
'Messiah wasn't even born in the heart of our winter, he was born in a time of early autumn, in the month of Tsim, which is the seventh month at the festival of Celtus or Tabernacles and they were always saying of it here, but this is the Feasts of the Jews. If you look at, let's say what we believe is the best English translation of the Bible, they can change but even there it is lacking because they've degraded the festivals of Yahwe to say it's the Feast of the Jews and there's no ways you will convince me otherwise the scripture tells me this are my feasts say the Lord ...' (P 3)
}

\section{Accommodating religious identities}

Accommodating identities relate to the experience of participants who have accommodated new aspects into their existing identity, with the main purpose of adapting to and surviving in the environment of incarceration. The notion of accommodating identity stems from the experience of accommodating new knowledge, behaviours and attitudes as a result of group affiliation while being incarcerated. The following quotations illustrate this notion:

'Because when God called me He said I am a prophet. Ja but now through my studying I passed, I am no longer a prophet I'm an apostle, a teacher, a pastor, they are in me these things.' (P 4)

The participant has now taken on a leadership role, which earns him more respect from correctional authorities and enhances his self-esteem. Another participant relates that he is still a Christian but a different kind of Christian, as he views himself as an 'eternalist', who believes that eternal life starts when one is born and not when he or she dies. As such, he has become God $[l y]$ on earth and specifically placed as such in this correctional facility:

'Ja like I tell you I'm more spiritual now and I am more an eternalist now than a Christian. Do you understand? I'm more eternalist than a Christian, so it has changed. I'm a different person than I used to be.' (P 5)

These quotations illustrate that identity can be refined or accommodative when one encounters new information or knowledge, and new insights and skills to accommodate oneself in a situation of incarceration. In terms of IPA, the researchers will not make comments at this stage on the [un] healthiness of the newly assumed roles of the participants. We solely focussed on the meaning these roles give to the participants. 
Therefore, as offenders interact with religious groups, they are more likely to assimilate and integrate new belief systems, behaviours and perspectives into their existing religious identity. However, not only do they accommodate new knowledge and religious skills, they also use their religious identity to adapt to their strenuous circumstances - where they have been deprived of much of their human dignity - by assuming leadership roles that are afforded to them only by their (accommodating) religious identity. This experience can be supported by Haslam et al. (2009:2), who states that religious beliefs and religious affiliation play a role in the shaping of the social and psychological processes.

\section{Contra-identities}

The theme of contra-identities stems from the notion of contrasting identities, where participants changed their identity during the course of incarceration. The new identities gave meaning to the offenders who felt that they had lost a sense of identity - and were forced to assume a predominantly criminal identity - when they were sentenced. The new identities were formed as a result of both individualistic and group affiliative processes. Contra-identities unfolded in various ways, namely, church/religious affiliation and spiritual identity. The following quotations illustrate this notion:

'My family is Christian, but I changed to Muslim when incarcerated. I felt that I am not giving God enough attention. As a Christian I just pray and sing on Sundays. I wanted to experience going down on the ground every day 5 times. What is special about the Islam religion is that it gives very strict rules, they have a specific way of doing a thing. It makes me feel safe.' (P 6)

The participant reports that prior to his incarceration he noticed that there was something lacking in his life while being a Christian. It appears that being a Muslim gave the meaning of fellowship and intimacy with God, which he was looking for. The structured daily routines prescribed by the Muslim religion provided meaning to his life, by drawing his attention to God and reducing time spent on delinquent behaviours.

Another participant's experience is different, in that his narration taps on a shifting identity between church affiliations. His narration depicts a shift from the Advent Presbyterian Church in Ocala Florida to being an elder in the DRC during incarceration. Being affiliated with the DRC provides him with a sense of belonging as the church enforced the use of his native language, which was different from his previous church. Similarly, Greenfield and Marks (2007:247) mention that formal participation in the religious/social group tends to enhance the social identities of individuals, which become an integral part of a holistic identity structure of an individual:

'Actually, that's a ... I attended various churches in Sentraal [Advent Presbyterian Church in Ocala Florida] and when I came here I found that there was an Afrikaans church. Now although they call it the Dutch Reformed Church, we speak mostly Afrikaans in the church because it's ... worshipping in the native tongue is different than worshipping in your secondary or tertiary language, I'm the elder of the Dutch Reformed Church here in the prison of Zonderwater.' (P 7)

In contrast to this, another Afrikaans-speaking participant has changed his religious affiliation from right wing Christian to atheist, and yet another from mainline Christian to 'Brahmanism'.

Contrasting again to this movement away from Christianity is the testimonies of participants who have moved away from 'being unreligious' to becoming fundamentally Christian - and that this move has led to the drastic modification of behaviour. In these cases, it appears that religiosity has shaped both the identity and behaviour of the participants. The following quotes illustrate this notion:

'I am now from a Gangster to a Servant. I was taking from people and now I am giving to people.' (P 8)

'You see transforming is not a thing of one day, to change it is a process, and you must be patient with people as God was patient with me. I've changed my character. I've changed my character, I've changed my language, I've changed many things, you see?' (P 9)

From the above quotations, several deductions can be made regarding religion and behaviour. Choosing to be religious tends to help participants not to re-offend and this notion is supported by the researcher, indicating that individuals who are extremely religious tend to refrain from risky behaviours (Ysseldyk et al. 2010:62). Furthermore, religiosity modifies the identity and/or character of the participant, thus, suggesting the interrelatedness of religious identity and the day-to-day conduct or behaviour (Ysseldyk et al. 2010:62). In summary, choosing a contrasting (a)religious identity gives participants a sense of belonging, hope and identity, and influences their choice for a preferred behaviour. This can be supported by the following extracts:

'Religion gives me hope. Religion is more of living a life of hope. ... now when you say ... when you go through the teachings of the Bible they will tell you about the glory that God has to us ... and it will be stretched. I can now live a good life.' (P 10)

'Islam gives him hope. He has seen it becoming real before. Just want to see children. Moreover, their forgiveness. Hope for a healthy family life. Islam teaches me to live as a good man.' (P 6)

'It gives me direction and clear mind. For example, when I get frustrated I pray about it.' (P 11)

'Since I have become an atheist, I care more about people than about God. I am a better person now.' (P 12)

In conclusion, it appears that the experience of conserving, accommodating and shifting identities gives participants meaning during incarceration, and that their preferred religious identity changes or maintains 'good' behaviour that assists them to deal with the demands of life in a correctional facility. Furthermore, the affiliation with religious or social groups serves as a form of support in maintaining or changing their behaviour and well-being by giving them hope and a sense of belonging. 


\section{Change of behaviour, attitudes and values}

From the reflections by the participants in this study, insight is gained into the changes in their attitude and behaviour, particularly regarding their spirituality as a continuous, evolving process in the environment of being incarcerated:

'How I have changed spiritually ... is on intellectual, logical, not on an emotional level.' (P 13)

'You know it's something you have no conception of, there's no way you can prepare yourself for the next 45 years. I've gone through phases of growth, going and regression.' (P 13)

'God keeps on kicking me, kicking my doors down and my heart, He wasn't just knocking, He was kicking the doors ... and since I have never ever stopped worshiping and praising him.' (P 7)

A behavioural response includes actions, or intentions to act, towards an object. What this means is that attitudes are formed through the knowledge people gain, which leads them to form certain beliefs. Attitudes are furthermore formed through emotional experiences and past experiences that in turn affect and direct behaviour (Nordlund 2009:4).

The participants in our study reflected on how their spiritual journey assisted in changing undesirable attitudes and behaviour. Through this process they gained knowledge, not just about religion or spirituality, but more so self-knowledge. In the discussion on how their attitude and behaviour have been changed with the help of a developing religiosity, they referred primarily to the acquisition of tolerance and patience:

'[ I changed] absolutely. Because, what does God say? Not in your time but in my time. Isn't that very, very, very important? Especially for a guy like me that never had any tolerance or patience.' (P 7)

'Sometimes God made me do things in his plannings ... I can see now I changed and I think, I don't just do things now.' (P 25)

Attitudes or beliefs, according to conventional societal norms, are displayed in religion - and in views towards criminal behaviour - as good or bad, right or wrong, justified or unjustified (Nicholson \& Higgins 2017:13). In search of the meaning of the situation they are in, and to develop an attitude to cope with it, the participants chose to define themselves as spiritual beings who are in a good relationship with God:

\footnotetext{
'All that matters are salvation and God is ... an obstacle race with traps for the intellects ... and senses ... Pascal's ... intellect compelled him to reject ... the God of his choice ... a belief he passionately desired ... a matter of faith increasingly at war with his intellect.' (P 13)

'I know that God chose me and that is a purpose to be here and I have a purpose here today to confess everything and to bring my testimony to you.' (P 16)
}

Values are distinguished from attitudes, in that values are regarded as generalised concepts, whereas attitudes refer to individualised standards (Rokeach 1973:3). To further our discussion on behaviour, we draw on the Value Theory of
Schwartz, who echoes Rokeach's view of values as generalised concepts of beliefs, which stand central to the development of the self, personality and identity (Schwartz 1992:1). Values are critical motivators for behaviour and attitudes and determine what is important in life (Schwartz 2012:17). The relationship between values and identity is important; a person needs to be authentic or committed to his established self, to behave in keeping with his values and beliefs (Hitlin 2003:123). Values, furthermore, function as a guide in the evaluation of events and in giving meaning to difficult life situations.

Schwartz (2012:5-7) identify 10 universal values for coping in our day-to-day existence. Values need to comply with three requirements to which all individuals and societies respond, namely (1) they must address the needs of the individual as biological being; (2) they must allow for coordinated social interaction; and (3) they must guarantee the survival and welfare of the needs of a group. Within the scope of our study with male offenders, who are part of a group in a set facility, some understanding should be acquired of how they cope with being incarcerated. As explained by Schwartz (2012:4), it is through our values that we acquire meaning. As echoed by Kiesling et al. (2006:1269), we define religious identity as a persistent sense of self that addresses ultimate questions about the nature, purpose and meaning of life, resulting in behaviours that are consonant with the individual's core values. The identified values directed by our goals are as follows:

Self-direction values refer to our independent thoughts and actions in the freedom to choose our own goals. Kiesling et al. (2006:1273) point to the importance of the role of freedom and independence in forming a religious identity, as was also emphasised by participants in our study. Serving life or long-term sentences, we found that the participants awarded themselves the freedom to continuously reconstruct their lives and find new meaning and purpose in their day-to-day existence, as they shared the following:

'You can put me here for life, for me, this life that I have, this one, is for the next life. That is just for advance for me. If, ma'am you see I can sit here, and I can be free. My mind can be free.' (P 7)

'Here you have two choices, you trust God, or you don't trust Him.' (P 8)

'I start at the beginning. As if started all over, even though I knew the Bible very well.' (P 9)

Stimulation values refer to the need for variety to experience and explore new exciting challenges in life. Respondents from a study by Kiesling et al. (2006:1273) expressed how this as a spiritual value changed their lives from distressful and painful, to enjoy the excitement of breaking new ground in self-exploration. Participants in our study articulated this as follows:

'Prison takes you out of your circumstances and it gives you time to re-asses.' (P 10) 
'I have this reformed side of me. Prefer a church where there's depth in the theology. Substance.' (P 15)

'My faith and that what the Word of God says ... and I have really put effort into the Bible, because I didn't have the knowledge I have today.' (P 14)

'I have started actually read religious books, which I never did, started studying religious books ... to know the contents of the Bible, for the first time, reading stuff that I have never read before, receiving messages, which I did not know.' (P 11)

This stimulation is also sought from others who share a spiritual enthusiasm. Participants in our study reported a desire for more interaction with fellow inmates on religious level, even if from other denominations:

'When growing up religion was strict, ... to know God you had to figure out yourself. Growing up we didn't discuss religion.' (P 14)

'You are withholding information from us, from which we can learn. We need to share and learn.' (P 14)

'He [a fellow inmate] will not just tell you something, he will say to you ... he can say it so beautifully. You know that man can mean so much for us. Here is a couple of our fellow black inmates that ask me every day "why aren't we having church anymore"?' (P 14)

'He knows his Bible. And if he answers you, you know he doesn't just say something. He will say it in such a way, that you don't feel he is pretending to be intelligent, he is very intelligent.' (P 14)

Hedonism, as defined by Schwartz (2012:5), refers to the need for pleasure or gratification and finding enjoyment in life. In the field of psychology, 'hedonism' is regarded as one of the main motivators of human behaviour, which is to seek pleasure (Veenhoven 2003:1). In the context of our study, it signifies the fulfilment individuals can experience in their spiritual journey even while incarcerated:

'I can't believe it when I ... with him ... we enjoy chatting, 3 hours non-stop, but if I meant it. It is immensely enjoyable to take the Bible. Wow it's just nice.' (P 14)

'I have Holy Communion on my own as well. I buy myself Provitas and then I make some cold drink. Now that is my most enjoyable time. Then I'm alone in my cell and I enjoy it tremendously.' (P 14)

Achievement and power values both focus on our self-esteem, where achievement values focus more on our personal accomplishments as demonstrated through our active participation and interaction with others, according to our social, cultural values system (Schwartz 2012):

'I wanna work from sunrise to sunset, I just wanna be an instrument in the hand of a living God to be a blessing to anyone that crosses my path.' (P 3)

'He will restore his people. So, I want a miracle to come out here and tell the people outside.' (P 16)

'I'm looking for a chance to prove myself ... I know I will make a meaningful contribution in many aspects.' (P 14)

Power values focus more on the attainment or preservation of our position within a social system. Both power and achievement values focus on social esteem. Achievement values emphasise the active demonstration of successful performance in concrete interaction (e.g. ambition), whereas power values emphasise the attainment or preservation of a dominant position within the more general social system (e.g. authority or wealth) (Schwartz 2012:5). Within the correctional environment, a different social system exists, with different rules, but this does not diminish the essence of the offenders' need for preservation of their social esteem, their ambitions or desire to still achieve success on a particular spiritual level:

'I have a desire ... to preach like Angus Buchan. Not in church, more Missionary.' (P 14)

Security values are basic needs derived from individual and group interests and requirements, aiming at security for oneself and others. Needs for and feelings of security, as explained by participants, are placed in God as remarked:

'I trust in what God has planned for me. Whatever God has planned for me, I'm happy.' (P 7)

'I know Yahweh is in control.' (P 16)

Conformity, according to Schwartz (2012:6), relates to values that emphasise self-restraint actions that are applied to everyday interaction, and include self-discipline, politeness, obedience, honouring your parents and elders, loyalty:

'I would pray about it and I would leave it in God's hands. I won't force the issues to change, I'll let God help me change things.' (P 7)

'I'll be responsible, accountable, child of God that lives the Word.' (P 7)

The topic of conformity has, however, received some critique in the past, as it was often seen as a blind conformity to religious norms, a lack of cognitive sophistication and a narrow compassion limited to only in-group members (Watson \& Morris 2005:371). The contrary is, however, more relevant today in a more open-minded religious search for meaning. Evidence to this was echoed by participants who chose not to conform to what was known to them and how they were brought up in terms of their religion. A conscious, well-studied decision was made by individuals to change, and they often chose to make a total change in religion, church or denomination, for example, from Christianity to Muslim, Christianity to New Israelites, and conform to a new set of practices and rules:

'I need the structure of my religion. I also pray God will forgive me for what I have done. Everything is asked in a specific prayer.' (P 6)

'I actually enjoyed that it was totally different from the experience I had at NG [Dutch Reformed] church. I won't look at religion being within a specific church. A specific church doesn't make it a religion.' (P 11)

Tradition values involve a process whereby individuals develop symbols, ideas and beliefs that represent their shared religious experiences valued by group customs and 
traditions. These values often relate closely to religious practices, rites and norms of behaviour and it is this homogenous faith tradition that defines an individual's sense of religious identity (Kiesling et al. 2006; Schwartz 2012). Tradition and conformity values, as Schwartz elaborates (2012:6), aim at sharing closely, subordinating one's self to social expectations. Conformity relates more to frequent interactions with significant people in one's daily life, whereas traditional values are more on an abstract level, where we react to current, changing expectations that often demand responsiveness to expectations from the past:

'But you know I'm still quite spiritual ... and look for a community or people that think and believe like you.' (P 13)

'I know how I've been raised, so I cannot disrespect how my grandmothers raised me.' (P 17, author's own translation)

Benevolence values, as described by Schwartz (2012:7), refer to the concern of people for the welfare of others. It involves honesty, forgiveness, responsibility, promoting one another's sense of belonging and respect for one another's spiritual life. It involves those of our in-group with whom we have frequent personal contact. Benevolence and conformity values both promote supportive social relations. Benevolence values provide an internalised motivational base for behaviour, whereas conformity values encourage cooperation to avoid negative outcomes for the self (Schwartz 2012:7). Evident to this is the almost testimonial responses shared by the participants:

'Look at me and see God in me.' (P 7)

'My job is to confront people to ask if God would be happy with what they are doing.' (P 7)

'Who I was and who I am now is a miracle if you compare the two people. If I could change, you can change.' (P 7)

'Something I really want, reconcile with the family that put me here.' (P 12)

'I will physically go to schools and talk to kids about what not to do.' (P 7)

Universalism values combine concern for those in the larger society, beyond the close in-group, with concerns for the world and nature at large, involving values such as social justice, equality, world peace, unity with nature, wisdom, a strive for inner harmony and a deepening of spiritual life. Schwartz (2012:7) explains that these values are derived from people's survival needs as individuals and groups need each other. It is acknowledged that survival depends on accepting others' differences and on treating everybody just and equal. Some of the participants' responses capture these universal values:

'Something I really want, reconcile with the family that put me here.' (P 12)

'God wants me to work with old people when I get released from here. Children and old people.' (P 7)

'I know that God chose me and that is a purpose to be here, and I have a purpose here today to confess everything and to bring my testimony to you.' (P 16)

'Spread the Gospel at old age homes.... a lot of very, very lonely people.' (P 7)
Finally, it needs to be noted that Schwartz's Values Theory (2012:7) acknowledges that spirituality constitutes another near-universal value, in that the defining goal of spiritual values is that it transcends everyday reality by giving meaning, coherence and inner harmony. If finding ultimate meaning is a basic human need, then spirituality might be a distinct value found in all societies where it shapes behaviour, and ultimately results in change.

\section{Conclusion}

This study deals with four themes, namely: conserving identities; accommodating identities; contra-identities; and change of behaviour, attitudes and values. Although these themes are presented as independent, they cannot be seen in isolation, but rather, dependent on and supporting one another. This concluding section discusses the interrelations and the significance of these findings in relation to SIT.

With regard to the first theme, the notion of conserving has been evident in the narratives, where participants denote that their religious identity has remained the same despite their criminal identity that was prevalent at the time of incarceration. The narratives suggest that despite behavioural changes that occurred as a result of being incarcerated, the essence of who they are has largely remained the same, mainly because religious affiliation was kept intact, and even deepened. The notion of conserving suggests the influence that social and religious affiliations have on shaping the identity of an individual. Furthermore, it suggests that identity formation is both an individualistic and group process. The idea that they regard their identity as stable could indicate the strength that group characteristic factors such as norms have on the individuals' socio-cognitive system (Greenfield \& Marks 2007:247).

The second theme is accommodating identities, where participants were accommodative towards new values, norms, knowledge and religious identity. These new ways of understanding themselves as spiritual beings gave them hope and a new meaning towards their day-to-day experience of being incarcerated. Despite mentioning the struggles of being incarcerated such as isolation, guilt and struggling with forgiveness, accommodating new sets of beliefs and behaviour gave them meaning to live and to what is being considered as a 'life driven by the right principles'. New, contextual identities also enabled the participants to accommodate the challenges of their situation of incarceration and acquire skills of adaptation, which they did not have before.

According to SIT, group affiliation can influence social-concept, self-esteem and regulate norms and behaviour. Furthermore, religious affiliation can potentially shape both psychological and social processes (Greenfield \& Marks 2007:247). This second theme focussed on the participants' accommodation in a new church or religion in the correctional facility. This was evident in the narratives of participants who mentioned that when they were incarcerated they had to leave their primary 
church and find a religious group that could accommodate their beliefs and ideologies. The notion of accommodating identities is relevant here, as participants mentioned that despite changes in beliefs, ideology and religious ritual and behaviours, the essence of who they are has largely remained the same. When exploring this theme further, aspects such as culture of origin and culture of a correctional facility were evident in explaining accommodating identities. For example, participants lamented on their culture of origin as being important to them; however, the norms and principles prescribed by their newly chosen religious affiliation give them meaning in dealing with the loss of freedom while being incarcerated. Similarly, Haslam et al. (2009:1) suggest that identification with social groups is important for emotional belongingness and well-being. Thus, religious groups and affiliation enhance feelings of belonging and self-esteem.

The third theme relates to contra-identities and suggests the assumption of new roles and identities in the correctional facility. This ranged from being a religious leader such as a priest, prophet, healer and teacher, to turning to atheism and eastern philosophies. These new identities contradicted with their former identities, which had the connotation of criminality and unlawfulness. It also contradicted their previous religious affiliations. When exploring the narratives, it appears that there were shifting identities and assumptions of new identities by participants after incarceration. The shift in identities emanated from affiliation with religious and/or church groups, which provided a set of beliefs and prescribed an acceptable behaviour and attitudes. The unique characteristics of a social group formed may mediate the individual's (newly contextualised) worldview and regulate behaviour and attitude towards their current life circumstances. Lastly, the notion of contra-identities could be explained by the experience of being incarcerated, which tends to rehabilitate criminal behaviour through psychological and spiritual interventions in addition to the correctional facility system, which punishes criminal behaviour. These aspects interact together in shaping new identities, values and ideologies about life, therefore mediating what is meaningful for participants during incarceration.

In terms of the theme of behaviour, attitude and values, we made deductions through the narrations of participants on how, as offenders within a very different setting, they attach and find meaning of their life as incarcerated. They adapt and adjust their behaviour through a fixed set of or newly acquired values and shaped attitudes. Of interest and worth exploring further is how participants explore and are open to gain knowledge of different religions, systems or spiritual disciplines. In almost all interviews, accounts were provided of how their experiences and spiritual journeys could go beyond tradition and set borders or barriers. Religious insights and experiences were often combined and the best of all taken to express themselves, and assist in making sense of life, their circumstances and their being. This view is supported by Van Niekerk (2018:9) that a 'new spiritual landscape' has developed that transcends traditional religious conformity.
The isolated environment, within which offenders find themselves, requires them to reconstruct a new society or social system. It is in this regard that the findings of this study, in terms of sociology, are significant, by echoing the sentiments of one of the first sociologists, Emile Durkheim (1857-1917) regarding the role of religion and spirituality within a social context. Their stories reflect, not just individualistic experiences, but that of true to human nature by establishing social relations, through shared social and moral beliefs (Durkheim 2001:viii). These findings contribute to an understanding of how those incarcerated indeed can find meaning and purpose beyond a life that is often perceived as mundane and with no direction (McGivern 2014:475). This contributes not only to their individual well-being and growth but also extends to their relationships inside as well as outside this environment. This promotes social cohesion, regulates behaviour and provides support in times of adversity and transitions in life (McGivern 2014:475). Through social interaction, the practice of their religious or spiritual beliefs furthermore supports the rehabilitative processes of the Department of Correctional Services.

It is evident that in their spiritual journey through communication and socialisation with others, participants rediscover, re-assess and reshape themselves and their lives. The value of this study is most appreciated in the sense that this was a journey of discovery for all involved, participants and researchers, where pollination took place, and it is inspiring to note how all embraced the process. The outcomes achieved confirm that the approach applied in terms of IPA succeeded in determining the essence and meaning that participants articulate to their religion and identity.

\section{Acknowledgements}

The process of applying for ethical clearance from the Department of Correctional Services was driven by Mbongiseni Mdakane, who originally conceptualised the project.

\section{Competing interests}

The authors declare that they have no financial or personal relationship(s) that may have inappropriately influenced them in writing this article.

\section{Authors' contributions}

C.L., H.J.N. and T.P. equally contributed to the writing and research of this article.

\section{References}

Ashforth, B.E. \& Mael, F.A., 1989, 'Social identity theory and organization', The Academy of Management Review 14(1), 20-39. https://doi.org/10.5465/amr. 1989.4278999

Bandura, A., 1971, Social learning theory, General Learning Press, New York.

Bandura, A., 1999, 'A social cognitive theory of personality', in L. Pervin \& O. John (ed.), Handbook of personality, 2nd edn., pp. 154-196, Guilford Publications, New York. (Reprinted in D. Cervone \& Y. Shoda (eds.), The coherence of personality, Guilford Press, New York.) 
Bolander, P. \& Sandberg, J., 2013, 'How employee selection decisions are made in practice', Organization Studies 34(3), 285-311. https://doi.org/10.1177/017084 0612464757

Brambilla, M., Manzi, C., Regalia, C., Becker, M. \& Vignoles, V., 2016, 'Is religious identity a social identity? Self-categorization of religious self in six countries', Psicologia Sociale 2, 189-198.

Durkheim, E., 2001, The elementary forms of religious life, transl. C. Cosman, Oxford University Press, New York.

Greenfield, E.A. \& Marks, N.E., 2007, 'Religious social identity as an explanatory facto for associations between more frequent formal religious participation and psychological well-being', The International Journal for the Psychology of Religion 77(3), 245-259. https://doi.org/10.1080/10508610701402309

Haslam, S.A., Jetten, J., Postmes, T. \& Haslam, C., 2009, 'Social identity, health and wellbeing: An emerging agenda for applied psychology', Applied Psychology: An International Review 58(1), 1-23. https://doi.org/10.1111/j.1464-0597.2008.00379.x

Hitlin, S., 2003, 'Values as the core of personal identity: Drawing links between two theories of self', Social Psychology Quarterly, Special Issue: Social Identity: Sociological and Social Psychological Perspectives 66(2), 118-137. https://doi. org $/ 10.2307 / 1519843$

Kiesling, C., Sorell, G.T., Montgomery, M.J. \& Colwell, R.K., 2006, 'Identity and spirituality: A psychosocial exploration of the sense of spiritual self', American Psychological Association 42(6), 1269-1277. https://doi.org/10.1037/0012-1649. 42.6.1269

Landman, C., 2005, 'Sexuality and spirituality in a South African female correctional centre', Scriptura 90, 789-798. https://doi.org/10.7833/90-0-1067

McGivern, R., 2014, 'Religion', in W. Little \& R. McGivern (eds.), Introduction to sociology 1st Canadian Edition, pp. 473-492, OpenStax College, Rice University, Texas city, TX.

Meyer, W., Moore, C. \& Viljoen, H., 2008, Personology: From individual to ecosystem, 3rd edn., Heinemann Publishers, Sandown, South Africa.

Nicholson, J. \& Higgins, G.E., 2017, 'Social structure social learning theory: Preventing crime and violence', in B. Teasdale \& M.S. Bradley (eds.), Preventing crime and violence, advances in prevention science, $\mathrm{pp}$. 11-20, Springer International Publishing, Switzerland.

Nordlund, A., 2009, Values, attitudes, and norms. Drivers in the future forests context. External drivers affecting Swedish forests and forestry, Future Forests Working Report, viewed n.d., from https://www.slu.se/globalassets/ew/org/centrb/f-for/ pdf/2009-nordlund-values-attitudes-and-norms.pdf.

Pietkiewicz, I. \& Smith, J.A., 2014, 'A practical guide to using interpretative phenomenological analysis inqualitative research psychology', Psychological Journal 20(1), 7-147.
Rokeach, M., 1973, The nature of human values, The Free Press, New York.

Riley, J., 2000, 'Sensemaking in prison: Inmate identity as a working understanding', Justice Quarterly 17(2), 359-376. https://doi.org/10.1080/ 07418820000096361

Schwartz, S.H., 1992, 'Universals in the content and structure of values: Theoretical advances and empirical tests in 20 countries', Advances in Experimental Socia Psychology 25, 1-65. https://doi.org/10.1016/S0065-2601(08)60281-6

Schwartz, S.H., 2012, 'An overview of the Schwartz theory of basic values', Online Readings in Psychology and Culture 2(1), 1-20. https://doi.org/10.9707/2307 0919.1116

Smith, J.A., 2004, 'Reflecting on the development of interpretative phenomenological analysis and its contribution to qualitative research in psychology', Qualitative Research in Psychology 1(1), 39-54.

Smith, J.A. \& Osborn, M., 2008, 'Interpretative phenomenological analysis', in J.A. Smith (ed.), Qualitative psychology: A practical guide to research method, pp. 53-80, Sage, London.

Shaw, R., 1995, Chaplains to the imprisoned, Haworth Press, New York.

Tajfel, H. \& Turner, J.C., 1986, 'The social identity theory of intergroup behavior', in S. Worchel \& W.G. Austin (eds.). The psychology of intergroup relations, pp. 277-293, Nelson-Hall, Chicago, IL.

Terre Blanche, M., Durheim, K. \& Painter, D., 2012, Research in practice, 2nd edn., University of Cape Town Press, Cape Town.

Turner, J.C., Hogg, M.A., Oakes, P.J., Reicher, S.D. \& Wetherell, M.S., 1987, Rediscovering the social group: A self-categorization theory, Basil Blackwell, Oxford.

Turner, J.C., Oakes, P.J., Haslam, A. \& McGarty, C., 1994, 'Self and collective: Cognition and social context', Personality and Social Psychology Bulletin 20, 454-463. https://doi.org/10.1177/0146167294205002

Van Niekerk, B., 2018, 'Religion and spirituality: What are the fundamental differences?', HTS Teologiese Studies/Theological Studies 74(3), 1-11. https://doi. org/10.4102/hts.v74i3.4933

Veenhoven, R., 2003, 'Hedonism and happiness', Journal of Happiness Studies (special issue on 'Art of living') 4, 437-457.

Watson, P.J. \& Morris, R.J., 2005, 'Spiritual experience and identity: Relationships with religious orientation, religious interest, and intolerance of ambiguity', Review of Religious Research 46(4), 371-379. https://doi.org/10.2307/3512167

Windholz, G., 1986, 'Pavlov's religious orientation', Journal for the Scientific Study of Religion 25(3), 320-327. https://doi.org/10.2307/1386296

Ysseldyk, R., Matheson, K. \& Anisman, H., 2010, 'Religiosity as identity: Toward an understanding of religion from a social identity perspective', Personality and Socia Psychology Review 14(1), 60-71. https://doi.org/10.1177/1088868309349693 